\title{
Towards an integration of the ecological space paradigm and the capabilities approach
}

\author{
Peeters, Wouter; Dirix, Jo \& Sterckx, Sigrid
}

\section{[in press at Journal of Agricultural and Environmental Ethics]}

\begin{abstract}
:
In order to develop a model of equitable and sustainable distribution, this paper advocates integrating the ecological space paradigm and the capabilities approach. As the currency of distribution, this account proposes a hybrid of capabilities and ecological space. Although the goal of distributive justice should be to secure and promote people's capabilities now and in the future, doing so requires acknowledging that these capabilities are dependent on the biophysical preconditions as well as inculcating the ethos of restraint. Both issues have been highlighted from the perspective of the ecological space paradigm. Concerning the scope of distributive justice, the integration can combine the advantages of the ecological space paradigm regarding the allocation of the responsibilities involved in environmental sustainability with the strength of the capabilities approach regarding people's entitlements. The pattern of distribution starts from a capability threshold. In order to achieve this threshold, ecological space should be provided sufficiently, and the remaining ecological space budget could then be distributed according to the equal per capita principle.
\end{abstract}

\section{Key words:}

Distributive justice, social justice, environmental sustainability, capabilities, ecological space

\section{Introduction}

Although countries across the world have been converging towards higher levels of human development, the global situation is characterized by both social injustice and unsustainability. First, despite the observable progress, there are still large disparities in, for example, income and health (United Nations Development Programme - UNDP 2013, p. 23). Second, the gains in human well-being over the last decades have been achieved at a cost, including the degradation of ecosystems, substantial and irreversible losses in biodiversity, increased risks of nonlinear changes (such as disease emergence and abrupt regional climate shifts) (MEA 
2005, p. 1; Schellnhuber et al. 2005, p. 13). Anthropogenic climate change is a prominent example of human-induced changes to the environment and represents one of the most serious and far-reaching challenges facing humankind. Driven by an unsustainable rate of anthropogenic greenhouse gas (GHG) emissions over the past few decades, human influence has led to unequivocal warming of the climate system and many changes that are unprecedented over decades to millennia (Intergovernmental Panel on Climate Change IPCC 2013, p. 2). Without mitigation, climate change is projected to result further inter alia in sea level rise, floods, increased frequency and magnitude of extreme weather events (such as storms, heatwaves and droughts), biodiversity loss and changes in precipitation patterns (Costello et al. 2009, pp. 1698-1699; McMichael \& Lindgren 2011, p. 402; Meehl et al. 2007, pp. 782-789). These events are already impacting human life: for example, a conservative estimate attributes a disease burden of 5.5 million disability adjusted life years lost in 2000 to climate change (Costello et al. 2009, pp. 1700-1701). Yet, future people will suffer most from the harmful consequences of unmitigated climate change. Effects on human life include increased mortality (related to, for example, the increased frequency and magnitude of heatwaves), food and water insecurity, the spread and exacerbation of diseases, conflicts resulting from resource scarcity, and increased migration (Confalonieri et al. 2007, pp. 396406; Costello et al. 2009, pp. 1700-1701; McMichael \& Lindgren 2011, pp. 403-404; McMichael et al. 2008, p. 192). Mitigation is therefore vital in order not to exacerbate the adverse effects of climate change and to reduce the root cause of the problem (Füssel 2007, p. 265; Jamieson 2005, p. 222-224). This clearly illustrates the need to respect the ecosphere's biophysical constraints. ${ }^{1}$

Social justice (which focuses on equity and people's quality of life) and environmental sustainability (which most fundamentally requires that human activities be confined within the ecosphere's biophysical constraints) are most often regarded as compatible objectives, assuming that environmental sustainability is a precondition for social justice and/or that social justice produces environmental sustainability (Dobson 2003, p. 84). Yet, this compatibility depends on the respective conceptions of both objectives (the determination of their defining terms as well as policy strategies to achieve them), which might also conflict: increasing social justice could be achieved at the cost of a deteriorating environment and vice

\footnotetext{
${ }^{1}$ Since climate change already affects people's well-being and the climate will continue to change for the foreseeable future due to the accumulated GHGs and the inertia of the climate system, an equitable climate policy should also comprise adaptation and compensation measures (Caney 2009, pp. 126-27; Füssel 2007, p. 266; Jamieson 2005, p. 222; Klein et al. 2007, p. 750). Nonetheless, due to space constraints, we cannot address these aspects here.
} 
versa (Dobson 1998, p. 3). For example, economic growth is still widely considered to be the most appropriate strategy to maintain and increase people's quality of life, although it is clearly environmentally unsustainable. Vice versa, reducing aggregate environmental impacts without recognizing people's developmental entitlements or unfairly distributing the burdens involved in mitigating climate change cannot be acceptable. Neither environmental sustainability nor social justice has such overriding legitimacy: neither an environmentally sustainable but socially unjust society, nor a society that is socially wholly just, yet destined for swift ecological collapse, would be acceptable. In sum, 'both objectives will continually vie for attention' (ibid., p. 4).

Therefore, building on the Brundtland Commission's definition of sustainable development (World Commission on Development and Environment - WCED 1987, p. 41) and the third principle of the Rio Declaration (United Nations Conference on Environment and Development - UNCED 1992), the aim of this paper is to develop a model for equitable and sustainable distribution, in order to secure and promote the developmental and environmental preconditions for current as well as future people's quality of life. ${ }^{2}$

Any account of distributive justice has to answer at least three questions: what is distributed (currency)?; who are the legitimate recipients and providers of (re)distribution (scope)?; and according to which principle(s) should distribution take place (pattern)? Moreover, in view of the fact that neither social justice nor environmental sustainability have overriding legitimacy, a comprehensive account of distributive justice needs to clarify how both the objectives of social justice and environmental sustainability are incorporated on all three dimensions. The goal of this paper is to advocate an integration of the Ecological Space Paradigm (ESP) and the Capabilities Approach in order to combine their advantages on all three dimensions in a comprehensive account of equitable and sustainable distribution. At the outset, however, we should like to point out that this paper can only provide a general sketch of the integrative account; a detailed analysis of all the related issues falls beyond its scope.

\section{Currency: what is distributed?}

According to Hayward (2007, pp. 445-446), ecological space 'comprises all the environmental goods and natural resources that play a part in the socio-economic life of

\footnotetext{
${ }^{2}$ This focus on justice between contemporaries and between current and future people does not include historical responsibility. We cannot adequately address this issue here, although we believe that the historical record gives rise to crosscutting implications regarding social justice as well as environmental sustainability. In addition, issues of justice towards the environment also fall beyond the scope of this paper.
} 
humankind.' We use it here as shorthand to denote the provisional, regulating, cultural, and supporting services that ecosystems and the Earth as a whole deliver (MEA 2005, p. 39-46; Steffen et al. 2011, p. 740). The ESP has been operationalized in several ways, most importantly, the distribution of GHG emissions permits, the Ecological Footprint (e.g. Wackernagel \& Rees 1996), and the Safe Operating Space for Humanity (SOSH) (Rockström et al. 2009). ${ }^{3}$

The Earth's ecosystems and the services they provide are the preconditions for human life (MEA 2005, p. 1; Rockström et al. 2009, p. 474). One of the key insights and major strengths of the ESP is precisely that in order to secure and sustain these biophysical preconditions for everyone - now and in the future - humanity has a moral obligation to refrain from transgressing the ecosphere's biophysical constraints (Chambers et al. 2000, p. 2; Rockström 2009, p. 472; Ross 2009, p. 54). In other words, those of us currently over-consuming and over-polluting 'require the inculcation of an ethic, an ethos, of restraint to accompany and underpin the recognition of our obligations to reduce our demands on resources' (Hayward 2009, p. 290).

Nonetheless, important remaining methodological issues and scientific uncertainties (predominantly regarding target-setting and defining biophysical constraints) ${ }^{4}$ indicate that the identification of the ecosphere's biophysical constraints ultimately depends on political agreement and normative choice - which is difficult in the current global political situation that is characterized by large inequalities in resources and entitlements (Biermann 2012, p. 6). Consider for example target-setting regarding climate change mitigation. There is general political agreement that global warming should be limited to $2^{\circ} \mathrm{C}$ above pre-industrial levels (see for example United Nations Framework Convention on Climate Change - UNFCCC 2009, Paragraph 1). Some scientific accounts have adopted this $2^{\circ} \mathrm{C}$ threshold as the starting point for determining the maximum allowable GHG emissions (for example, Allen 2009, p. 114; Rockström et al. 2009). However, since emissions continue to track the average of the most carbon-intense scenarios put forward by the Intergovernmental Panel on Climate Change, the $2^{\circ} \mathrm{C}$ target becomes less plausible as a realistic goal since a rise of at least $4^{\circ} \mathrm{C}$

\footnotetext{
${ }^{3}$ Other operationalizations of the ESP include Environmental Utilization Space (Opschoor \& van der Straaten 1993), Material Flow Analysis (Bringezu \& Moriguchi, 2002), Industrial Metabolism (Ayres 1997) and other indicators of environmental sustainability.

${ }^{4}$ Methodological issues have been predominantly discussed regarding the Ecological Footprint (e.g., van den Bergh \& Grazi, 2010; van den Bergh \& Verbruggen 1999; Fiala 2008), although Nature Reports Climate Change has dedicated a special issue to scrutiny of the SOSH framework (Vol. 3(10), October 2009; e.g. Allen 2009). A discussion of these methodological issues falls beyond the scope of this paper. Some of the most important normative issues are mentioned in the remainder of this section, although as yet, they arguably remain underdeveloped in the literature.
} 
increasingly becomes unavoidable (Le Quéré, 2009, p. 831; Dirix et al. 2013). Moreover, this is not only a methodological issue, but also a normative one, for it involves the questions of how much climate change is acceptable and to what extent we are willing or able to mitigate global warming: identifying "dangerous" climate change is "a complex task that can only be partially supported by science, as it inherently involves normative judgements' (Rogner et al. 2007, p. 99). Indeed, despite general political agreement regarding the $2^{\circ} \mathrm{C}$ target, the Alliance of Small Island States (AOSIS) has declared that global warming must be kept well below $1.5^{\circ} \mathrm{C}$ (2012, Paragraph $\left.8 \mathrm{~A}\right)$, since they are especially vulnerable to and already experiencing climate change adversities (AOSIS 2012, Paragraph 1-3; UNDP 2011, pp. 35-36). In contrast, richer societies - who have polluted most - might be disinclined to adopt more conservative thresholds, because these require most mitigation efforts from them first, while they have the greatest interest in the continuation of the current system (Biermann 2012, p. 6; Gardiner 2006, p. 401).

Even in view of these methodological, normative, and political complications, Biermann insists that a framework such as the SOSH is likely to develop into a powerful political narrative - as Ecological Footprint Analysis arguably already is. Moreover, all the operationalizations mentioned above clearly show that humanity is currently transgressing the ecosphere's biophysical constraints. To mention but one example, the key finding of Rockström and colleagues (2009, p. 472) in their analysis of the SOSH is that humanity has already left its safe operating space by trespassing the planetary boundaries of at least three systems (biodiversity loss, climate change and interference with the nitrogen cycle), and is rapidly approaching several other boundaries (freshwater use, land-system change and, arguably, ocean acidification). In sum, even though the scientific uncertainties and methodological issues remain significant, the ESP undeniably shows that humanity's current demands are unsustainable and that action is urgently needed for tackling climate and other adverse environmental changes.

Yet, despite these insights, designating ecological space as the currency of distribution faces certain objections. It has been observed that ecological space is an all-purpose means required to have a good quality of life, rather than being a direct measure of well-being (Page 2007, pp. 460-461). Sen (1979, p. 216; 1990, pp. 119-120) has argued that such resourcist accounts have an element of 'fetishism', because they focus on means rather than ends, whereas quality of life should be conceived as a relationship between persons and goods. Indeed, for example, GHG emission permits (but also other parts of ecological space) only have instrumental value in relation to their ability to pursue various goals (Caney 2009, p. 
130). Moreover, many issues of social justice - such as the political underrepresentation of women or personal disadvantages related to mental or physical illness - cannot be traced to environmental problems or to the appropriation of environmental goods (Page 2007, p. 461). Since ecological space as the currency of distribution is only indirectly connected to human well-being, it seems unable to provide a comprehensive focus of our distributive concerns. In sum, the ESP cannot be said to offer a complete account of distributive justice, for even though it delivers valuable insights on environmental sustainability, it is inadequate to capture issues of social justice beyond the distribution of environmental goods and services.

In view of his objections to resourcist accounts, Sen (1999, p. 74) advocates a focus on 'the substantive freedoms - the capabilities - to choose a life one has reason to value', rather than on the means to freedom. However, the capabilities approach's emphasis on the value of individual freedom - including the possibly infinite expansion of people's material freedoms and capabilities - cannot adequately address environmental sustainability (Crabtree 2010, p. 163; Peeters et al. 2013, pp. 63-64). Indeed, the issues central to environmental sustainability have only recently been taken up by capability theorists (see e.g. Holland 2008; Lessmann 2011; Lessmann \& Rauschmayer 2013; Pelenc et al. 2013; Schultz et al. 2013). These debates mainly point towards two problematic issues in the capabilities approach related to environmental sustainability: first, it arguably disregards the importance of the biophysical preconditions for enjoying capabilities; and second, it has not yet exhaustively addressed the imperative of environmental sustainability that fundamentally requires humanity to refrain from transgressing the biophysical constraints of the ecosphere. Addressing these two issues and connecting the environmental dimension with human flourishing that is central to social justice solicits the input of theories external to the capabilities approach (Schultz et al. 2013, p. 130). Therefore, especially in light of the advantages mentioned above, we argue that the ESP can offer certain insights needed to incorporate the importance of the biophysical preconditions as well as the requirement to refrain from transgressing the ecosphere's biophysical constraints.

First, the capabilities approach does recognize the central importance of the health of ecosystems for allowing people to lead the lives they value (Anand \& Sen 2000, p. 2030; Sen 2010, p. 130; 2013, pp. 7-8; Nussbaum 2011, p. 163). Nonetheless, this acknowledgement of the role of the environment as a key dimension of human wellbeing remains ambiguous in both Sen and Nussbaum's versions of the capabilities approach (Holland 2008, p. 320; Pelenc et al. 2013, p. 78). Therefore, Holland (2008, p. 323) has proposed the addition of Sustainable Ecological Capacity as a meta-capability, which encompasses the ecological conditions that 
can provide environmental resources and services that enable people's range of capabilities now and in the future. The ESP and its concretizations offer information about the ecological conditions and the sustainable appropriation of the environmental resources and services.

In accordance with Holland's account, we propose to differentiate between social and material preconditions for enjoying capabilities. For example, the bodily integrity capability includes being able to move freely from place to place (Nussbaum 2006, p. 76), which clearly presupposes the availability of material conditions (such as adequate transportation), as well as particular social conditions (for example, robust traffic regulations). As the ESP clearly shows, material justice - securing these material conditions for everyone - 'has its own precondition, namely the integrity of the compendious resources of the biophysical world' (Hayward 2009, p. 292). Differentiating between social and material (and thus, environmental) preconditions for enjoying capabilities acknowledges our dependency on the environment, rather than interpreting capabilities as 'a set of disembodied freedoms' (Jackson 2009, p. 45).

Second, the assumption of environmental sustainability that 'the current generation might have to restrict itself in some ways (e.g. restrict its consumption) in order to ensure the preservation of the opportunity for a full life for future generations' has not yet been given profound theoretical consideration by the main protagonists of the capabilities approach (Lessmann 2011, p. 50). For example, in their attempt to deal with the issue of sustainable development, Anand and Sen (2000, p. 2038) focus on enhancing current people's capabilities as not only intrinsically important, but also instrumentally important in increasing their "human capital" with lasting influence in the future,' which should be seen as a major contribution to the achievement of sustainability. This might be true in cases such as women's empowerment and reproductive rights, which are inherently valuable and have positive spillover effects on the environment through reducing fertility rates (Sen 1999, p. 226; 2009, p. $249 ; 2013$, p. 15 ; UNDP 2011 , pp. $73-75) .{ }^{5}$ In other cases, however, this account begs the question, for improving people's capabilities usually takes its toll on the environment, especially when the development model is premised on ecological abundance and includes the possibility of infinite economic expansion (see also Crabtree 2010, p. 163; Rauschmayer et al. 2011, p. 13). Indeed, although the capabilities approach criticizes the mere focus on economic growth for being an insufficient basis for human development and for having little intrinsic merit, at the same time, it affirms economic growth as an important means to expand people's

\footnotetext{
${ }^{5}$ The UNDP has used Sen's capabilities approach as the conceptual basis in its analysis of contemporary development challenges in its annual Human Development Reports (Fukuda-Parr, 2003, p. 302).
} 
freedoms (see for example Anand \& Sen 2000, p. 2030; Nussbaum 2006, pp. 70-71; Sen 1999, p. 3; UNDP 2013, p. 21). Since economic expansion (and population growth) has negated the positive effects of increased efficiency (i.e., decreasing the resource intensity of production), the inculcation of an ethic of restraint in material consumption is a vital strategy for attaining environmental sustainability (Huesemann 2004, p. 267; Jackson 2009, p. 67; Mont \& Plepys 2008, p. 531). However, the capabilities approach cannot adequately scrutinize or constrain the material - often luxury - consumption of the elite and the middle classes, since that would clash with the freedom and sovereignty of consumers and therefore, with the liberal neutrality between conceptions of the good life that is one of the central tenets of the capabilities approach (Mont \& Plepys 2008, p. 531; Peeters et al. 2013, pp. 63-64).

One clear principle of restraint provided by liberalism and accepted (but not yet thoroughly investigated) by the capabilities approach is the harm principle (Mill 2008, p. 14; Deneulin 2002, p. 510; Nussbaum 2000, p. 53). Yet, applying it to, for example, the issue of climate change is challenging, since the latter 'is not a matter of a clearly identifiable individual acting intentionally so as to inflict an identifiable harm on another identifiable individual, closely related in time and space' (Jamieson 2006, pp. 476-477). Shue (2001, p. 450), in contrast, maintains that the emitters of avoidable GHGs can be held responsible for the resultant infliction of physical harm. Elsewhere, we have attempted to develop the harm principle to address the responsibilities and obligations of current towards future people from the capabilities perspective, which led us to conclude that the insights of the ESP are indispensable for addressing distributive justice between current and future people (Peeters $e t$ al. 2013). Moreover, it might be questioned whether the harm principle is sufficient to build an adequate ethos of restraint from within liberalism, since restraint might also assume 'reevaluating the nature and extent of the benefits we ourselves draw from our activities, even when these do not immediately or obviously precipitate some harm on others' (Hayward 2009, p. 291). Thus, for example, materialist lifestyles might be criticized independently of their environmental impact for resulting in the 'damaging social logic of consumerism' (Jackson 2009, p. 102), and for leading to consumer anxiety, work stress and lack of time to enjoy other (e.g. social, cultural and political) activities. ${ }^{6}$ Nonetheless, the question arises as

\footnotetext{
${ }^{6}$ Hayward (2009, pp. 290-293) mentions that the imperative of restraint is not only a matter of the right (through its focus on the harm principle and the universal right of access to the necessary means for a decent life, which include biophysical assets), but a matter of the good as well, since it gives rise to a 'green' conception of the good life and to 'green' virtues. However, the capabilities approach does not accept this latter interpretation, because it conflicts with the value the capabilities approach places on liberal neutrality between conceptions of the good life (Nussbaum 1998). Moreover, we would like to note that a reevaluation of the benefits people draw from their material consumption in our example can also be merely informative regarding the trade-offs they
} 
to how to evaluate the benefits of our activities, because the ESP's focus on the means necessary for well-being is vulnerable to Sen's criticism of "fetishism" mentioned above. The benefits from environmental appropriation should therefore be evaluated in terms of social justice - and thus quality of life - but given its focus on resources, the ESP is inadequate to do this.

In sum, we recommend integrating the ESP and the capabilities approach. On the one hand, the currency of distribution should reflect the focus on people's entitlements and their ability to pursue flourishing - a key part of the capabilities approach. On the other hand, distribution should take account of the preconditional character of the integrity of ecosystems by differentiating between material (and environmental) and social conditions for enjoying capabilities, based on the information about environmental resources and services provided by the ESP. Moreover, an ethos of restraint - to which the ESP clearly draws our attention should be incorporated. We will return to operationalizing the latter when discussing the pattern of distribution, but we must first turn to the question of scope.

\section{Scope: who are the legitimate recipients and providers of (re)distribution?}

While other currencies of distributive justice (such as welfare, resources and, as we will explain below, capabilities) are primarily designed to apply to relations of distribution between contemporaries, with their intertemporal implications being a matter of further deliberation, 'ecological space turns this methodological approach on its head by embracing an explicit commitment to intergenerational justice at the outset' (Page 2007, p. 461). Central to the ESP is the protection of the physical integrity of ecosystems that provide the material preconditions for current as well as future people's well-being. The ESP shows that humanity's current material demands exceed the carrying capacity, which constitutes injustice towards future people since their quality of life will be adversely affected.

Through this focus on the unjust impacts of human activity on environmental integrity, the ESP is consistent with the preservation of the earth's ability to sustain life, a central requirement of justice towards future people (Chambers et al. 2000, p. 46; Page 2007, p. 460). However, its applicability to distributive justice between contemporaries remains questionable, since the ESP does not adequately address social justice: it merely focuses on

might experience between material prosperity and social participation - both of which they might value without necessarily advocating a particular conception of the good life. However, since these issues need further analysis, we limit discussion here to the interpretation of the imperative of restraint as a matter of the right. 
the means to achieve a good quality of life and many inequities are not traceable to the appropriation of ecological space.

In contrast, the advantage of the capabilities approach is that it captures well-being directly in terms of freedom, which we consider to be essential for justice between contemporaries as well as for social justice in general. Yet, the applicability of the capabilities approach towards future people remains a matter for deliberation and is increasingly discussed in recent literature. Anand and Sen (2000, p. 2030) have attempted to open the scope of the capabilities approach to include future people in the community of justice, arguing that sustainability reflects the universality of life claims: 'the recognition of a shared claim of all to the basic capability to lead worthwhile lives.' They argue that, since we do not know which preferences and capabilities future people will value, 'we can talk of sustainability only in terms of conserving a capacity to produce well-being' (ibid., p. 2035). However, rather than being substitutable by human capital (as Anand and Sen appear to claim), the ESP shows that the biophysical preconditions are pivotal in maintaining the capacity to produce well-being. Hence, the universality of life claims requires the protection and expansion of people's capabilities today, while at the same time acknowledging the ecosphere's biophysical constraints in order to protect the environmental preconditions on which future people's capabilities depend. This implies incorporating an ethos of restraint, which the capabilities approach has failed to inculcate, but to which the ESP is dedicated.

Another way of putting this is by referring to the differentiation between entitlement- and duty-bearer justice. According to Caney (2009, p. 127), the necessity of preventing dangerous climate change is predominantly concerned with people's entitlements that are jeopardised by climate change, but a robust climate policy would nonetheless be unfair if the duties involved were unfairly distributed. More generally, a coherent account of social justice and environmental sustainability involves adequately addressing both entitlements and duties. As regards entitlement-bearer justice, we agree with Anand \& Sen (2000, p. 2030) that ethical universalism is fundamentally an elementary demand for impartiality, applied between contemporaries as well as between current and future people. Therefore, we endorse the universality of life claims in terms of capabilities: current and future people share the entitlement to the basic capabilities required for a worthwhile life. ${ }^{7}$

\footnotetext{
${ }^{7}$ Others have attempted to resolve the non-identity problem, without a satisfactory solution (see Davidson 2008). Here, we can only contend that future people, by virtue of being human, will all be entitled to human rights and capabilities that are threatened by inter alia climate change (Shue 2011, p. 293; 2013, p. 395). This contention affirms the moral intuition of duties towards future people, and provides the grounds for treating transgressions
} 
However, according to Pelenc et al. (2013, p. 82), this notion of capability needs to be complemented with an appropriate view of responsibility. Indeed, Dobson (2006b, p. 169) argues that the "thin" notion of universal entitlements is insufficient to motivate us to shoulder our responsibilities and does not provide a rationale for distributing these responsibilities. In view of environmental sustainability, the affirmation of universal entitlements entails the collective duty to refrain from transgressing the ecosphere's biophysical constraints. However, although Nussbaum (2013, p. 478) seems to oppose further specification of who might have duties and when, an unspecified collective duty results in the well-known problem that each could pass the responsibility to someone else. Moreover, the burdens involved in discharging this collective duty should be fairly distributed, accounting for existing inequities. First, it should be acknowledged that not everyone suffers equally from environmental degradation (ibid., p. 19). For example, without appropriate redistributive policies, the social and economic costs of climate change will fall more heavily on the current poorest and future people (UNDP 2007, p. 64; Costello et al. 2009, p. 1694; Jamieson 2005, p. 227). Second, the ESP clearly shows that although we all partake in ecological space, we do not do so equally (Dobson 2006b, p. 176). These two observations point to the pervasive inequity of environmental impact, and the inverse relationship between environmental risk and responsibility (UNDP 2007, p. 43; Costello et al. 2009, p. 1694). The undistributed collective duty to refrain from transgressing the ecosphere's biophysical constraints might obscure these inequities.

Therefore, Dobson (2006b, p. 173) refers to causal responsibility as a more compelling rationale for allocating remedial responsibility. According to him, the globally and intertemporally inequitable occupation of ecological space directly implies the remedial responsibility of reducing ecological space occupation where appropriate (Dobson 2006a, p. 450). In other words, and in accordance with the ethos of restraint, duty-bearer justice involves the assignment of remedial responsibility to "ecological debtors" - people who exceed their fair share of ecological space - and requires of them a commitment to reduce their environmental impact to the permitted level (Hayward 2006, p. 368; 2007, p. 445; 2009, p. 283; Vanderheiden 2009, pp. 265-266).

In sum, the integration of the ESP and the capabilities approach meets the need to address issues of both entitlement- and duty-bearer justice. While the capabilities approach emphasizes impartiality and the universality of life claims as the core of entitlement-bearer

of the ecosphere's biophysical constraints as a wrongful harm - not only to current, but also to future people (see also Davidson 2008, p. 482). 
justice, the ESP specifies the collective duty inherent to environmental sustainability on the basis of causal responsibility and ecological debt.

\section{Pattern: according to which principle(s) should distribution take place?}

While Sen's comparative approach to justice does not yield a specific distributive principle, Nussbaum (2006, p. 71; 2013, pp. 478, 485-486) argues that the goal of social policies should be understood in terms of getting citizens above a certain capability threshold beneath which human functioning is not available. According to her, people are entitled 'to a life compatible with human dignity, and this entitlement means that the relevant goods must be available at a sufficiently high level' (ibid., p. 292). She distinguishes between capabilities related to human dignity - to be secured equally - and instrumental capabilities that should be secured sufficiently (ibid., pp. 292-293). As mentioned above in our discussion of the currency of distribution, we would rather make the differentiation within capabilities: each capability requires that the corresponding social and material conditions be satisfied. First, in order for people to reach the threshold, social conditions must be secured equally, since they are closely related to human dignity and respect - in which cases it is the equal human dignity and respect that demands recognition (Shue 1999, p. 532; see also Nussbaum 2006, p. 292).

Second, the remainder of this section will focus on the appropriate principle for distributing the material conditions, which ultimately rely on ecological space. Indeed, an equal distribution of ecological space might not be consistent with human dignity or the capability threshold. Take for example the future allocation of GHG emissions entitlements, ${ }^{8}$ the most obvious and intuitive defense of which starts from the equal per capita principle (Gardiner 2004, p. 583; Caney 2009, p. 130). Many defend an egalitarian distribution of GHG emissions (for example Jamieson 2005, p. 231) and a variant is advocated in the Contraction and Convergence proposal (Meyer 2000). Furthermore, politically, the equal per capita principle has been advocated by most of the developing countries, including China and India (Gardiner 2004, p. 583 n90). However, since the conversion of resources into freedoms and opportunities may vary from person to person, an egalitarian distribution 'can go hand in hand with serious inequalities in actual freedoms enjoyed by different persons' (Sen 1990, p. 115). According to Sen (1990, pp. 111-112, 120-121; 1999, pp. 70-71), these interpersonal

\footnotetext{
${ }^{8}$ In this section, we will focus on the distribution of GHG emissions entitlements, since the discussion about the pattern of distribution is most advanced in this literature. It should be clear, however, that we consider ecological space also to comprise other essential environmental assets.
} 
variations - connected inter alia with gender, genetic endowment, and social and cultural conditions - must form a crucial part of the informational basis of justice, but cannot be incorporated by an egalitarian account of resource distribution. Caney (2009, p. 130, emphasis in original) states that it is therefore implausible to focus on distributing resources equally, 'if doing so will leave people unequal in their ability to pursue various goals.'

In view of this objection, a promising basis for modifying the equal per capita proposal might be provided by Shue's (1993, pp. 56-59) normative differentiation between subsistence emissions and luxury emissions. According to him, 'minimum vital emissions could be viewed as an inalienable private property right, or simply a human subsistence right' (Shue 2001, p. 455). While subsistence emissions permits should be handed out for free in order not to make the life of the poor impossible, emission permits beyond the necessity threshold should be paid for and be tradable, implying that the rich would bear the burden of climate change mitigation (Shue 1993, p. 59; 2001, p. 455; 2011, p. 307). This account has been developed further by Vanderheiden (2008, p. 243), whose modified equal shares model starts from the claim that 'all persons are entitled as a matter of basic rights to survival emissions, or a level of emissions sufficient to allow for their basic human functioning.' These survival emissions should be distributed so as to meet everyone's basic rights, while remaining luxury emissions should be distributed on an equal per capita basis (ibid., pp. 226-227, 243). Such a modified equal shares model might partly meet Sen's concerns about interpersonal variations, since it encompasses people's differential abilities to reach subsistence.

We should like to emphasize that people are entitled 'not only to mere life, but to a life compatible with human dignity' (Nussbaum, 2006, p. 292) and hence, the focus on subsistence or survival should be reformulated as a capability threshold. The focus ultimately remains on securing people's capabilities, and GHG emissions entitlements should be distributed so as to allow everybody to reach the threshold. Considering the capability threshold as the central criterion of distribution shows the important yet instrumental value of GHG emission entitlements. This insight might pre-empt a forceful objection against considering subsistence emissions as a fundamental right. Meeting people's rights to subsistence emissions, Gardiner (2004, p. 585) argues, might have undesirable implications for attempts to tackle climate change: 'if some emissions are deemed morally essential, then they may have to be guaranteed even if this leads to an overall allocation above the scientific optimum.' This objection has also been voiced by Hayward (2007, p. 432-433), who asserts that we should deny that there is any human right to emissions; rather there is a human right to live in an unpolluted environment. According to him, the worst off do have a right of access 
to the means for a decent life, but 'emissions are not inherently necessary to fulfill that right' (ibid., p. 432). The problem revealed by the fact that carbon emissions are currently necessary to secure subsistence for most people, is that they are locked into a carbon dependent economy. Shue (2001, p. 451; 2013, p. 392 esp. n. 34) acknowledges this issue, and emphasizes that the need for access to GHG emissions in order to reach subsistence is a function of the energy regime that is in place. As long as the lack of affordable sustainable energy makes many or most dependent on fossil fuels, they should be allowed to emit the GHGs necessary to reach the capability threshold level. Obviously, however, the development of alternatives could enable people to reach the threshold with less GHG emissions - and this strategy is clearly necessary to mitigate climate change without exacerbating poverty (Shue 2013). Thus, the focus of developmental policies should be on the advancement of alternative energy, in order to reduce carbon dependence as soon and thoroughly as possible. Accordingly, the input of the capabilities approach in the integration might tackle the observation that GHG emissions are instrumentally, rather than inherently necessary for a good life.

A sufficientarian principle of distribution based on the capability threshold does not yet fully inculcate the ethos of restraint to which the ESP is dedicated. Environmental sustainability requires that people should refrain from exceeding their fair share of ecological space, and thus that their functionings beyond the capability threshold should be constrained in terms of their ecological space usage (Peeters et al. 2013, pp. 70-71). Indeed, in mitigating climate change, the second front of action - in addition to the development of alternatives to fossil fuels - is clearly that carbon emissions need to be cut back sharply (Shue 2011, p. 313). As regards the distribution of GHG emissions permits beyond the capability threshold, we agree with Vanderheiden (2008, pp. 226-227, 243; see above) that the egalitarian principle might be a good candidate. Although this would not meet Sen's objection regarding interpersonal variations, it might be questioned whether equity requires taking account of interpersonal variations in attaining luxury, since people have an interest, but weaker or no rights to luxury emissions (Vanderheiden 2008, p. 243).

However, some issues related to the determination of the capability threshold have yet to be addressed. Determining what counts as necessary GHG emissions in order to reach the capability threshold seems procedurally odd, for such proposals appear 'to envisage that the climate change problem can be resolved by appealing to some notion of social necessity that is independent of, and not open to, moral assessment' (Gardiner 2004, p. 586). Merely focussing on the capability threshold - without a normative assessment of the environmental 
impact of the GHG emissions necessary to achieve it - will not contribute to climate change mitigation. Moreover, there is 'the implication that there is not necessarily any upper limit to the inefficient emissions that would be permissible in order to reach what might be necessary' (Hayward 2007, p. 441). Finally, such proposals carry the political risk that there is nothing to stop some people claiming that almost any emission is essential to their way of life (Gardiner 2004, p. 586).

These concerns are serious, and we can only briefly comment on them. Shue (2001, pp. 454-455) contends that the issue of exceeding the global tolerable total emissions budget by securing the minimum essential for each person is a matter of scientific determination. As argued above, however, scientific advances may well be insufficient to offer a comprehensive resolution, since these issues ultimately depend on political and normative choices. Additionally, regarding the precise determination of the capability threshold, Nussbaum (2006, p. 402; 2011, pp. 41-42) relies on democratic debate, stating that we should avoid specifying unrealistically high or unjustifiably low capability thresholds. Taking environmental sustainability (and climate change mitigation) seriously complicates these issues, since it raises fundamental, and perhaps uncomfortable, moral questions regarding what we consider a "desirable" or targeted future, how we should live, and what kinds of societies we want (Banuri et al. 2001, pp. 97-98; Gardiner 2006, p. 402; Jamieson 1992, p. 147). These questions illustrate the need to take account of both social justice and environmental sustainability: the determination of the precise thresholds must take account of people's entitlements as well as the ecosphere's biophysical constraints.

In sum, the integration of the ESP and the capabilities approach takes the capability threshold as its main feature. This threshold presupposes the equal provision of social conditions and the sufficient distribution of material conditions (and thus, ecological space). The ecological space remaining could be distributed on an equal per capita basis, which in effect constrains people's functionings in terms of their ecological space appropriation, consistent with an ethos of restraint.

\section{Conclusion}

A comprehensive account of distributive justice needs to incorporate the objectives of both social justice and environmental sustainability. To address the challenge of balancing the competing goals of ensuring current and future people's quality of life and living within the biophysical constraints, we have advocated integrating the ESP and the capabilities approach 
into an account that encompasses distributive justice between contemporaries as well as between current and future people.

Although admittedly there are methodological, political and normative complications in operationalizing ecological space, the ESP delivers key insights regarding environmental sustainability and the imperative of restraint in view of the ecosphere's biophysical constraints. However, the ESP seems unable to capture social justice, since it focuses on the means to achieve ends, whereas quality of life should be conceived as a relationship between persons and goods. The capabilities approach, in contrast, focuses on the substantive freedoms that are important for well-being, but it has not yet profoundly considered the central requirement of environmental sustainability, i.e. to refrain from transgressing biophysical constraints in order to secure and sustain the environmental preconditions for everyone - now and in the future. Therefore, as the currency of distribution, the integration proposes a hybrid of capabilities and ecological space. Distributive justice should aim at securing and promoting people's capabilities now and in the future, but should also acknowledge that these capabilities are dependent on material conditions - ultimately on biophysical preconditions which requires including the ethos of restraint to which the ESP is dedicated.

Concerning the scope of justice, we have argued that the integration can combine the advantage of the ESP regarding the distribution between current and future people with the strength of the capabilities approach regarding distributive justice between contemporaries. We take the universality of life claims - a key part of the capabilities approach - as the point of departure for entitlement-bearer justice and the application of impartiality, both between contemporaries and between current and future people. The ESP, on the other hand, urges people not to transgress the ecosphere's biophysical constraints in order to ensure the biophysical preconditions for future people. In this way, the ESP assigns moral responsibility to those who exceed their fair share of ecological space and requires them to reduce their environmental impact, which is an issue of duty-bearer justice.

As regards the distributive pattern, we have advocated starting from a capability threshold. In order for people to reach this threshold, social conditions should be secured equally, whereas material conditions - ultimately dependent on ecological space - should be provided sufficiently. A focus on the capability threshold, rather than the distribution of ecological space itself, can tackle the objection that ecological space is not inherently necessary for human flourishing. The ecological space remaining could then be distributed on an equal per capita basis. In line with this distributive pattern, development policies should clearly focus on making available affordable and sustainable alternatives, and on reducing ecological space 
appropriation. However, we admit that various issues related to the determination of the threshold in view of the ecosphere's biophysical constraints remain to be addressed.

\section{Acknowledgements}

We are grateful to Thomas Potthast and Simon Meisch for inviting us to contribute to this special issue. An earlier version of this paper was presented at the 2012 EURSAFE Conference (Tübingen, 30 May-02 June). We are grateful to the audience for their critical comments. We would also like to thank Lieske Voget-Kleshin, Sebastian Oberthür and two anonymous reviewers for their extremely helpful suggestions, and Julian Cockbain for his language editing.

\section{References}

Allen, M. (2009). Tangible targets are critical. Nature Reports Climate Change, 3(10), 114115.

Anand, S., \& Sen, A. (2000). Human development and economic sustainability. World Development, 28(12), 2029-2049.

AOSIS (2012). Alliance of Small Island States Leaders' Declaration. http://aosis.org/wpcontent/uploads/2012/10/2012-AOSIS-Leaders-Declaration.pdf. Accessed 14 November 2013.

Ayres, R. (1997). Industrial metabolism: Work in progress. http://flora.insead.edu/fichiersti_wp/inseadwp1997/97-09.pdf. Accessed 14 November 2013.

Banuri, T., Weyant, J., , Akumu, G., Najam, A., Pinguelli, R., Rayner, S. et al. (2001). Setting the Stage: Climate Change and Sustainable Development. In B. Metz, O. Davidson, R. Swart, \& J. Pan (eds.), Climate Change 2001: Mitigation: Contribution of Working Group III to the Third Assessment Report of the Intergovernmental Panel on Climate Change (pp. 73-114). Cambridge: Cambridge University Press. http://www.grida.no/climate/ipcc_tar/wg3/pdf/1.pdf. Accessed 14 November 2013. 
Biermann, F. (2012). Planetary boundaries and earth system governance: Exploring the links. Ecological Economics, 81, 4-9.

Bringezu, S., \& Moriguchi, Y. (2002). Material flow analysis. In R. Ayres, \& L. Ayres (eds.), A handbook of industrial ecology (pp. 79-90). Cheltenham: Edward Elgar.

Caney, S. (2009). Justice and the distribution of greenhouse gas emissions. Journal of Global Ethics, 5(2), 125-146.

Chambers, N., Simmons, C., \& Wackernagel, M. (2000). Sharing nature's interest. Ecological footprints as an indicator of sustainability. London: Earthscan.

Confalonieri, U., Menne, B., Akhtar, R., Ebi, K., Hauengue, M., Kovats, S., et al. (2007). Human health. In M. Parry, O. Canziani, J. Palutikof, P. van der Linden, \& C. Hanson (eds.), Climate Change 2007: Impacts, Adaptation and Vulnerability. Contribution of Working Group II to the Fourth Assessment Report of the Intergovernmental Panel on Climate Change (pp. 391-431). Cambridge: Cambridge University Press. http://www.ipcc.ch/pdf/assessmentreport/ar4/wg2/ar4-wg2-chapter8.pdf. Accessed 14 November 2013.

Costello, A., Abbas, M., Allen, A., Ball, S., Bell, S., Bellamy, R., et al. (2009). Managing the health effects of climate change. The Lancet, 373, 1693-1733.

Crabtree, A. (2010). Sustainable development, capabilities and the missing case of mental health. In K. Aagaard Nielsen, B. Elling, M. Figueroa, \& E. Jelsøe (eds), A new agenda for sustainability (pp. 159-176). London: Sage.

Davidson, M. (2008). Wrongful harm to future generations: The case of climate change. Environmental Values, 17, 471-488.

Deneulin, S. (2002). Perfectionism, paternalism and liberalism in Sen and Nussbaum's capability approach. Review of Political Economy, 14(4), 497-518.

Dirix, J., Peeters, W., Eyckmans, J., Jones, P., \& Sterckx, S. (2013). Strengthening bottom-up and top-down climate governance. Climate Policy 13 (3). 363-383. 
Dobson, A. (1998). Justice and the environment: Conceptions of environmental sustainability and theories of distributive justice. Oxford: Oxford University Press.

Dobson, A. (2003). Social justice and environmental sustainability: Ne'er the twain shall meet? In J. Agyeman, R. Bullard, \& B. Evans (eds), Just sustainabilities: Development in an unequal world (pp. 83-95). London: Earthscan.

Dobson, A. (2006a). Ecological citizenship: A defence. Environmental Politics, 15(3), 447451.

Dobson, A. (2006b). Thick cosmopolitanism. Political Studies, 54, 165-184.

Fiala, N. (2008). Measuring sustainability: Why the ecological footprint is bad economics and bad environmental science. Ecological Economics, 67 (4), 519-525.

Fukuda-Parr, S. (2003). The human development paradigm: Operationalizing Sen's ideas on capabilities. Feminist Economics, 9, 301-317.

Füssel, H. (2007). Adaptation planning for climate change: Concepts, assessment approaches, and key lessons. Sustainability Science, 2(2), 265-275.

Gardiner, S. (2004). Ethics and global climate change. Ethics, 114(3), 555-600.

Gardiner, S. (2006). A perfect moral storm: Climate change, intergenerational ethics and the problem of corruption. Environmental Values, 15, 397-413.

Hayward, T. (2006). Global justice and the distribution of natural resources. Political Studies, 54, 349-369.

Hayward, T. (2007). Human rights versus emissions rights: Climate justice and the equitable distribution of ecological space. Ethics and international affairs, 21 (4), 431-450. 
Hayward, T. (2009). International political theory and the global environment: Some critical questions for liberal cosmopolitans. Journal of Social Philosophy, 40 (2), 276-295.

Holland, B. (2008). Justice and the environment in Nussbaum's "Capabilities Approach": Why Sustainable Ecological Capacity is a meta-capability. Political Research Quarterly, 61(2), 319-332.

Huesemann, M. (2004). The failure of eco-efficiency to guarantee sustainability: Future challenges for industrial ecology. Environmental Progress, 23(4), 264-270.

IPCC (2013). Summary for policymakers. In T. Stocker, D. Qin, G.-K. Plattner, M. Tignor, S. Allen, J. Boschung, et al. (eds.), Climate change 2013: The physical science basis. Working Group I contribution to the Fifth Assessment Report of the Intergovernmental Panel on Climate Change. Cambridge: Cambridge University Press. http://www.climatechange2013.org/images/uploads/WGI_AR5_SPM_brochure.pdf. Accessed 14 November 2013.

Jackson, T. (2009). Prosperity without growth: Economics for a finite planet, London: Earthscan.

Jamieson, D. (1992). Ethics, public policy, and global warming. Science, Technology \& Human Values, 17 (2), 139-153.

Jamieson, D. (2005) Adaptation, mitigation, and justice. In W. Sinnott-Armstrong, \& R. Howarth (eds.), Perspectives on climate change: Science, economics, politics, ethics (pp. 217248). Amsterdam: Elsevier.

Jamieson, D. (2006). The moral and political challenges of climate change. In S. Moser, \& L. Dilling (eds.), Creating a climate for change: Communicating climate change \& facilitating social change (pp. 475-482). Cambridge: Cambridge University Press.

Le Quéré, C., Raupach, M., Canadell, J., \& Marland, G. (2009) Trends in the sources and sinks of carbon dioxide. Nature Geoscience 2, 831-836. 
Lessmann, O. (2011). Sustainability as a challenge to the capability approach. In F. Rauschmayer, I. Omann, \& J. Frühmann (eds.), Sustainable development: Capabilities, needs, and well-being (pp. 43-61). New York: Routledge.

Lessmann, O., \& Rauschmayer, F. (2013). Re-conceptualizing sustainable development on the basis of the capability approach: A model and its difficulties. Journal of Human Development and Capabilities, 14(1), 95-114.

McMichael, A., \& Lindgren, E. (2011). Climate change: Present and future risks to health, and necessary responses. Journal of Internal Medicine, 270(5), 401-413.

McMichael, A., Nyong, A., \& Corvalan, C. (2008). Global environmental change and health: Impacts, inequalities, and the health sector. BMJ, 336, 191-194.

MEA (2005). Ecosystems and Human Well-being: Synthesis. Washington DC: Island Press.

Meehl, G., Stocker, T., Collins, W., Friedlingstein, P., Gaye, A., Gregory, J., et al. (2007). Global Climate Projections. In S. Solomon, M. Qin, Z. Manning, M. Chen, K. Marquis, M. Averyt, et al. (eds.), Climate Change 2007: The Physical Science Basis. Contribution of Working Group I to the Fourth Assessment Report of the Intergovernmental Panel on Climate Change (pp. 747-845). Cambridge: Cambridge University Press, Cambridge. http://www.ipcc.ch/pdf/assessment-report/ar4/wg1/ar4-wg1-chapter10.pdf. $\quad$ Accessed 14 November 2013.

Meyer, A. (2000). Contraction and convergence: The global solution to climate change (Schumacher Briefing no. 5). Foxhole: Green Books.

Mill, J. S. (2008). On liberty [First published in 1859]. In J. S. Mill, On liberty and Utilitarianism (pp. 1-149). New York: Bantam.

Mont, O., \& Plepys, A. (2008). Sustainable consumption progress: Should we be proud or alarmed? Journal of Cleaner Production, 16, 531-537. 
Nussbaum, M. (1998). The good as discipline, the good as freedom. In D. Crocker, \& T. Linden (eds.), Ethics of consumption: The good life, justice, and global stewardship (pp. 312341). Lanham: Rowman \& Littlefield Publishers.

Nussbaum, M. (2000). Women and human development: The capabilities approach. Cambridge: Cambridge University Press.

Nussbaum, M. (2006). Frontiers of justice: Disability, nationality, species membership. Cambridge: The Belknap Press of Harvard University Press.

Nussbaum, M. (2011). Creating capabilities: The human development approach. Cambridge: The Belknap Press of Harvard University Press.

Nussbaum, M. (2013). Climate change: Why theories of justice matter. Chicago Journal of International Law, 13(2), 469-488.

Opschoor, H., \& van der Straaten, J. (1993). Sustainable development: An institutional approach. Ecological Economics, 7, 203-222.

Page, E. (2007). Intergenerational justice of what: Welfare, resources or capabilities? Environmental Politics, 16(3), 453-469.

Peeters, W., Dirix, J. \& Sterckx, S. (2013). Putting sustainability into sustainable human development. Journal of Human Development and Capabilities, 14(1). 58-76.

Pelenc, J., Lompo, M., Ballet, J., \& Dubois, J.-L. (2013). Sustainable human development and the capability approach: Integrating environment, responsibility and collective agency. Journal of Human Development and Capabilities, 14(1). 77-94.

Rauschmayer, F., Omann, I., \& Frühmann, J. (2011). Needs, capabilities and quality of life: Refocusing sustainable development. In F. Rauschmayer, I. Omann \& J. Frühmann (eds.), Sustainable development: Capabilities, needs, and well-being (pp. 1-24). New York: Routledge. 
Rockström, J., Steffen, W., Noone, K., Persson, A., Chapin, F., Lambin, E., et al. (2009). A safe operating space for humanity. Nature, 461(24), 472-475.

Rogner, H., Zhou, D., Bradley, R., Crabbé, P., Edenhofer, O., Hare, B., et al. (2007). Introduction. In B. Metz, O. Davidson, P. Bosch, R. Dave \& L. Meyer (eds.), Climate Change 2007: Mitigation: Contribution of Working Group III to the Fourth Assessment Report of the Intergovernmental Panel on Climate Change (pp. 95-116). Cambridge: Cambridge University Press. http://www.ipcc.ch/pdf/assessment-report/ar4/wg3/ar4-wg3-chapter1.pdf. Accessed 14 November 2013.

Ross, A. (2009). Modern interpretations of sustainable development. Journal of Law and Society, 36(1), 32-54.

Schellnhuber, H., Crutzen, P., Clarck, W., \& Hunt, J. (2005). Earth system analysis for sustainability. Environment, 47(8), 10-25.

Schultz, E., Christen, M., Voget-Kleschin, L., \& Burger, P. (2013). A sustainability-fitting interpretation of the capabilities approach: Integrating the natural dimension by employing feedback-loops. Journal of Human Development and Capabilities 14(1), 115-133.

Sen, A. (1979). Equality of what? In: S. McMurrin (ed.). The Tanner lecture on human values (vol. 1). Salt Lake City: University of Utah Press. http://tannerlectures.utah.edu/_documents/a-to-z/s/sen80.pdf. Accessed 14 November 2013.

Sen, A. (1990). Justice: means versus freedoms. Philosophy and Public Affairs, 19(2), 111121.

Sen, A. (1999). Development as freedom. New York: Alfred A. Knopf.

Sen, A. (2009). The idea of justice. London: Alan Lane.

Sen, A. (2010). Sustainable development and our responsibilities. Notizie di Politeia, 26(98), 129-137. 
Sen, A. (2013). The ends and means of sustainability. Journal of Human Development and Capabilities, 14(1), 6-20.

Shue, H. (1993). Subsistence emissions and luxury emissions. Law and Policy, 15(1), 39-59.

Shue, H. (1999). Global environment and international inequality. International Affairs, 75(3), $531-545$.

Shue, H. (2001). Climate. In D. Jamieson (ed.), A companion to environmental philosophy (pp. 449-59). Malden: Blackwell.

Shue, H. (2011). Human rights, climate change, and the trillionth ton. In D. Arnold (ed.), The ethics of global climate change (pp. 292-314). Cambridge: Cambridge University Press.

Shue, H. (2013). Climate hope: Implementing the exit strategy. Chicago Journal of International Law, 13(2), 381-402.

Steffen, W., Persson, A., Deutsch, L., Zalasiewicz, J., Williams, M., Richardson, K. et al. (2011). The anthropocene: From global change to planetary stewardship. AMBIO 40, 739-761.

UNCED (1992). Rio Declaration on Environment and Development. http://www.un.org/documents/ga/conf151/aconf15126-1annex1.htm. Accessed 14 November 2013.

UNDP (2007). Human Development Report 2007/2008. Fighting climate change: Human solidarity in a divided world. Basingstoke: Palgrave MacMillan. http://hdr.undp.org/en/media/HDR_20072008_EN_Complete.pdf. Accessed 14 November 2013.

UNDP (2011). Human development report 2011. Sustainability and equity: A better future for all. Basingstoke: Palgrave MacMillan. http://hdr.undp.org/en/media/HDR_2011_EN_Complete.pdf. Accessed 14 November 2013. 
UNDP (2013). Human development report 2013. The rise of the South: Human Progress in a diverse world. http://hdr.undp.org/en/media/HDR2013_EN_Summary.pdf. Accessed 14 November 2013.

UNFCCC (2009). Draft Decision -/CP.15 (Copenhagen Accord). FCCC/CP/2009/L.7. http://unfccc.int/resource/docs/2009/cop15/eng/107.pdf. Accessed 14 November 2013.

van den Bergh, J. \& Grazi, F. (2010). On the policy relevance of ecological footprints. Environmental Science and Technology, 44, 4843-4844.

van den Bergh, J., \& Verbruggen, H. (1999). Spatial sustainability, trade and indicators: An evaluation of the 'ecological footprint'. Ecological Economics, 29(1), 61-72.

Vanderheiden, S. (2008). Atmospheric justice. A political theory of climate change. Oxford: Oxford University Press.

Vanderheiden, S. (2009). Allocating ecological space. Journal of Social Philosophy, 40(2), 257-75.

Wackernagel, M., \& Rees, W. (1996). Our ecological footprint. Reducing human impact on the earth. Gabriola Island: New Society Publishers.

WCED (1987). Our Common Future [Brundtland Report]. http://www.un-documents.net/ourcommon-future.pdf. Accessed 14 November 2013. 